\title{
Oceaneering: Building In-House Expertise Through Accredited Training
}

\section{Stewart Elder}

\author{
Oceaneering International Services Limited, United Kingdom
}

\begin{abstract}
:
This paper aims to analyse the implications of oil price fluctuations for a competitive landscape in the oil and gas industry. As one of the global oilfield providers of engineered services and products primarily to offshore, Oceaneering evaluates the potential of building in-house expertise through accredited training. This approach would enable the company to develop necessary capabilities, ensuring that the current and future skills requirements are in sync with the company's plans.
\end{abstract}

Paper type: Case study

Keywords: Accredited training, OGAS, Oil and Gas industry, North Sea engineering 


\section{Introduction}

The oil and gas industry is recovering from the state of flux initiated by the plummeting oil's price in October 2014 (U.S. Energy Information Administration, 2015). While the price has been relatively stable since April 2015 (BBC News, 2015), it forced the crude oil producers to revise their costs structures and that also includes planning and retention of human resources. Previously, the labour market of the oil and gas industry was quite dynamic, with quick reallocation of employees across the projects, which led to additional contextual training of engineering and other technical staff. The new reality of cheap oil puts some competitive pressures on the oil and gas operators extracting oil, particularly in North Sea; 40 per cent of the firms surveyed said they had cut research and development spending and 46 per cent said they had cut spending on training, though the report states, 'some companies are using the quieter periods to increase in-house staff training' (McCulloch, 2015).

Different oil and gas operators pursue different coping strategies. Some might question the need to invest in training in the times when the industry is slowing down, whereas others try to find neater solutions. Orlando Zepeda, the chief officer of the oil and gas program at the Laredo Community College, maintains that 'the oil and gas industry is about taking risks. You've gotta take risks to be in the oil and gas industry', (McGovern, 2015). Investing in training is one of those necessary risks that might lead to fruitful results in future.

While salaries in the industry may have to become comparatively more competitive in the years ahead, oil and gas still looks set to remain a strong industry in which to build a career and business. The starting salaries for petroleum engineers are in the region of $£ 27,000$ to $£ 36,500$ (Prospects, 2013) and with experience and training it goes up to an average of $£ 42,357$ per annum (PayScale., 2015). According to Society of Petroleum Engineers (2012), upon starting their career, most employees still require training and expect their employer to be the main facilitator of it. Companies where training opportunities are lacking may be enough for employees to consider leaving and they may not attract the best candidates.

\section{Oceaneering International Services}

Oceaneering is one of the global oilfield providers of engineered services and products, primarily to the offshore oil and gas industry (Oceaneering, 2013). Oceaneering has a focus on deepwater applications and through the use of its applied technology expertise, it also serves the defence, entertainment and aerospace industries. Such widespread technology and service requires the continuous development of staff capabilities to keep up with technological advancements and future challenges. Some of these industry-wide challenges have been acknowledged by the oil and gas operators: lack of leadership skills by technical staff, ageing workforce and lack of interest among the younger generation for careers in the oil and gas industry.

International Journal of Management and Applied Research, 2015, Vol. 2, No. 3 
The career progression in the industry is based on the principle that experienced technical employees are being promoted from a craftsmen level to a foremen level or to even more senior management positions. Daum et al. (2014: 67) maintains that 'these skilled craftsmen went from being welders one month to foremen the next month, which doesn't necessarily mean they're good-quality supervisors'. Hence, acquiring leadership and mentoring skills is a necessity which should be addressed timeously by both an employee and an employer. Hence, in-house training is often seen as a sensible solution.

Working with the next generation of workers is also on the Oceaneering's agenda. It has been challenging to attract young people to work in the UK oil and gas industry (Oil Career, 2013). Young people, or the millennial generation, who were born between 1980 and 2000 more specifically, expect interesting career and they are likely to move on quickly if their expectations are not being met (Lyons, et al., 2012; PwC, 2011; Pfeffer, 2013). The job redundancies in the industry due to fluctuations in oil price (UKCS, 2013) and the hostile working conditions are naturally unattractive to the millennial generation. Additionally, the job prospects of young workers in the oil and gas industry for the next 40-50 years becomes uncertain since the output from oil reserves is in long-term global decline and alternate energy sources become more widely used. Therefore, accredited training programmes to ensure a degree of skills diversification from one sector to another are seen as a prudent solution for both workers and oil and gas operators.

Accredited training can play a key role in dealing with the industry-wide challenges, giving to individuals a recognised development path and for employers this signifies being in control of skilled, in-house, developed human resources. The Oil and Gas Academy of Scotland (OGAS) is working with organisations across the industry in the development of robust and transparent training recognition systems, using the internationally recognised Scottish Credit and Qualifications Framework. One such organisation is Oceaneering, the well-known global provider of engineered services and products to the offshore industry, which is working with OGAS on a project to accredit several of its Remotely Operated Vehicle (ROV)-related training courses. The OGAS credit rating service will provide an excellent opportunity to both reflect the quality of Oceaneering's world-class training programmes and provide individuals with internationally recognised certification.

There are clear benefits of such accrediting courses. For Oceaneering, the credit-rating framework will:

- help to attract talented individuals into the industry and to retain and motivate valuable staff

- provide a clear and consistent training structure across major organisations and training providers

- give employers more opportunity to offer employees continued professional development (CPD)

International Journal of Management and Applied Research, 2015, Vol. 2, No. 3 
- meet many of the requirements of the Scottish Government's Skills for Scotland Strategy

- help achieve a culture of real partnership between employers and education, where employers are co-investors and co-designers rather than simply customers

All individual Oceaneering employees who successfully complete credit-rated courses will have a robust record of participant achievement and assessments, using a sophisticated, internationally-accessible database that will also help provide a robust audit trail for quality assurance purposes. Hence, individuals can use the accredited courses as a potential route to gain additional formal qualifications provided by international further and higher education partners.

\section{Conclusion}

In summary, organising training in the oil and gas industry is not without certain challenges especially in the light of new realities of oil's pricing and intensified industry competition. The accredited courses will ensure that companies such as Oceaneering have access to a highly qualified workforce, whereas individuals in the industry will enjoy the internationally recognised certification leading to diversification of skills and expertise to facilitate a more stable career path.

\section{References}

1. BBC News (2015), "Oil price hovers at four-month high", $B B C, 27$ April, [Online] available at: http://www.bbc.co.uk/news/business-32480039[Accessed on 3 May 2015].

2. Daum, C., Duncan, S., \& Hoover, S. (2014), "Construction Labor Needs In Booming Oil, Gas Market”, Pipeline \& Gas Journal, Vol. 241, No. 3, pp. 67-69.

3. Lyons, S. T.; Schweitzer, L.; Ng, E.S.W. and Kuron, L. K. J. (2012), “Comparing apples to apples: A qualitative investigation of career mobility patterns across four generations", Career Development International, Vol. 17, No. 4, pp. 333 - 357. https://doi.org/10.1108/13620431211255824

4. McGovern, M. (2015), "LCC could spend millions for Oil and Gas program", $K G N S . t v, 4^{\text {th }}$ May,[Online] available from: http://www.kgns.tv/home/headlines/LCC-could-spend-millions-for-Oil-and-Gasprogram-302480051.html[Accessed on 5 May 2015].

5. McCulloch, S. (2015), "Survey: North Sea oil and gas firms report further slump in optimism", Daily Record, $1^{\text {st }}$ May, [Online] available from:

http://www.dailyrecord.co.uk/business/business-news/survey-north-sea-oil-gas5615840[Accessed on 2 May 2015]. 
6. Oceaneering (2013),About Oceaneering,[Online] available from: http://www.oceaneering.com/about/[Accessed on 2 May 2015].

7. Oil Career (2013), The global oil and gas workforce survey, [Online] available from:

http://oilcareers.com/content/downloads/blogs/workforce_survey_h2_2013.pdf [Accessed on 28 October 2013].

8. PayScaleinc.(2015), Petroleum Engineer Salary in the UK, [Online] available from : http://www.payscale.com/research/UK/Job=Petroleum_Engineer/Salary[Accessed on 3 April 2015].

9. Pfeffer, J. (2013), "You're Still the Same: Why Theories of Power Hold over Time and Across Contexts", Academy of Management Perspective, Vol. 27, No. 4, pp. 269-280. https://doi.org/10.5465/amp.2013.0040

10. Prospects (2013), Petroleum engineer: Salary and conditions, available from: http://www.prospects.ac.uk/petroleum_engineer_salary.htm[Accessed on 3 April 2015].

11. PwC (2011), Millennials at work: Reshaping the workplace, PricewaterhouseCoopers International Limited. [Online] available from: http://www.pwc.com/en_M1/m1/services/consulting/documents/millennials-atwork.pdf [Accessed on 25 March 2014].

12. Society of Petroleum Engineers (SPE) (2012), Training and Development Survey, SPE [Online], available from: http://www.spe.org/career/docs/12Training-andDevelopment-Study.pdf [Accessed on 3 April 2015].

13. UK Continental Shelf (UKCS) (2013), Oil \& Gas UK's 2013 Demographics Report, UK: UKCS [Online], available from: http://www.oilandgasuk.co.uk/cmsfiles/modules/publications/pdfs/EM012.pdf [Accessed on 30 October 2013].

14. U.S. Energy Information Administration (2015),Short-term Energy Outlook: Global Crude Oil Prices, [Online], available from: http://www.eia.gov/forecasts/steo/report/prices.cfm[Accessed on 13 May 2015]. 